\author{
Banco de México \\ Documentos de Investigación
}

Banco de México

Working Papers

$\mathrm{N}^{\circ} 2018-11$

\title{
Logging Concessions, Certification \& Protected Areas in the Peruvian Amazon: Forest Impacts from Combinations of Development Rights \& Land-use Restrictions
}

\author{
Jimena Rico \\ Stephanie Panlasigui \\ Banco de México \\ Duke University \\ Jennifer Swenson \\ Duke University \\ Alexander Pfaff \\ Duke University
}

Colby J. Loucks

World Wildlife Fund- US

August 2018

La serie de Documentos de Investigación del Banco de México divulga resultados preliminares de trabajos de investigación económica realizados en el Banco de México con la finalidad de propiciar el intercambio y debate de ideas. El contenido de los Documentos de Investigación, así como las conclusiones que de ellos se derivan, son responsabilidad exclusiva de los autores y no reflejan necesariamente las del Banco de México.

The Working Papers series of Banco de México disseminates preliminary results of economic research conducted at Banco de México in order to promote the exchange and debate of ideas. The views and conclusions presented in the Working Papers are exclusively the responsibility of the authors and do not necessarily reflect those of Banco de México. 
Documento de Investigación 2018-11

Working Paper

2018-11

\section{Logging Concessions, Certification \& Protected Areas in the Peruvian Amazon: Forest Impacts from Combinations of Development Rights \& Land-use Restrictions}

\author{
Jimena Rico ${ }^{\dagger}$ \\ Banco de México
}

\author{
Stephanie Panlasigui \\ Duke University
}

\author{
Colby J. Loucks ${ }^{\S}$ \\ World Wildlife Fund- US
}

\section{Jennifer Swenson \\ Duke University}

\section{Alexander Pfaff ${ }^{ \pm}$ \\ Duke University}

Abstract: In this paper, we use geospatial data and difference-in-differences models to identify the deforestation effects, during 2000-2013, of the leading forest policies in the Peruvian Amazon: i) logging concessions, ii) third-party certification of concessions, and iii) Protected Areas (PAs). We find that on average logging concessions have no effect on tree-cover loss, while the PAs do reduce loss. Further, the PAs allowing limited private extraction save more forest than do more restrictive PAs. Certification has an impact (reduces loss) only in the single region where concessions reduce loss, suggesting a complementarity of third parties with private and public efforts to govern concessions. Our results suggest roles for private rights within conservation, given oversight.

Keywords: certification, FSC, deforestation, concessions, protected areas, impact evaluation JEL Classification: Q23, Q56, Q24, O13

Resumen: En este trabajo utilizamos datos geoespaciales y modelos de diferencias en diferencias para identificar los efectos en la deforestación, durante 2000-2013, de las principales políticas forestales en la Amazonía peruana: concesiones forestales, certificación de terceros de las concesiones, y áreas protegidas (APs). Encontramos que, en promedio, las concesiones forestales no tienen un impacto en la pérdida de cobertura de árboles, mientras que las APs sí reducen la pérdida. Además, las APs que permiten a los agentes privados una extracción limitada salvan más bosques que las APs más restrictivas. La certificación tiene un impacto (reduce la pérdida) solamente en la única región donde las concesiones reducen la pérdida, sugiriendo una complementariedad de los terceros con los esfuerzos públicos y privados para gobernar las concesiones. Nuestros resultados sugieren roles de los derechos privados para la conservación, dada la existencia de supervisión.

Palabras Clave: certificación, FSC, deforestación, concesiones, áreas protegidas, evaluación de impacto

\footnotetext{
† Dirección General de Investigación Económica. Email: jimena.rico@banxico.org.mx.

‡ Nicholas School of the Environment. Email: stephaniepanlasigui@alumni.duke.edu.

§Wildlife Conservation. Email: colby.loucks@wwfus.org.

Nicholas School of the Environment. Email: jswenson@duke.edu.

\pm Sanford School of Public Policy. Email: alex.pfaff@duke.edu.
} 


\section{Introduction ${ }^{1,2}$}

Forest loss often follows demands for forest products and outputs of cleared lands, raising questions about the best ways to balance conservation with economic development. Tropical forest loss has been driven by myriad pursuits of both individual and societal economic development including legal and illegal logging and mining, the development of infrastructure, cattle ranching, and the expansion of industrialized agriculture (see, e.g., Laurance et al., 2001; Raschio, Contreras \& Schlesinger, 2014; DeFries, Rudel, Uriarte \& Hansen, 2010; Swenson, Carter, Domec \& Delgado, 2011; and Urrunaga, Johnson, Orbegozo, \& Mulligan, 2012). Despite forest growth in temperate zones - including in plantations -since 1990 there has been on average a net annual forest loss of 0.13 percent at the global level (FAO, 2015a). That represents a total net loss of forest over this time period of 129 million hectares - an area equivalent to the size of South Africa (FAO, 2015a).

Ecological impacts include erosion, degradation of water resources, species extinctions, and around fifteen percent of global carbon emissions (Laurance, Ferreira, Rankin de Merona \& Laurance, 1998; Laurance, 1999; van der Werf et al., 2009; Wright \& Muller-Landau, 2006). Linking back from carbon emissions to economic development, climate change is expected to lower economic growth, on average, while raising poverty (Arent et al., 2014).

\footnotetext{
1 This paper supersedes analyses concerning Peru found in Panlasigui, Rico, Swenson, Loucks and Pfaff (2015), a working paper titled "Early Days in the Certification of Logging Concessions: Estimating FSC's Deforestation Impact in Peru and Cameroon," in the Duke Environmental and Energy Economics Working Paper Series.

${ }^{2}$ We wish to thank Karen Mo, Milton Huanca, Nelson Gutiérrez, Rafael Venegas, Margarita Céspedes, Cecilia Álvarez, and Johana Deza of the World Wildlife Fund (WWF) for their assistance with context and data. We are grateful to Allen Blackman, Carlo Alcaraz, Uli Gräbener, Jeffrey Milder, Jack Putz, Magareta Renstrom, Aurelie Shapiro, Jaap Warde, and two anonymous reviewers from Banco de México for helpful feedback. We also thank Marco Romero, Giannina Rimarachin, Natalia Marius, Drago Bozovich, Alba Solís, Erik Fischer, the Amazon Conservation Association's staff in Peru, FSC Peru, and SERFOR's staff for valuable insights. Panlasigui and Rico are grateful for WWF's financial support for extensions of the research done for their master's projects at Duke University.
} 
Policies have attempted to conserve forest while allowing economic activities - yet studies of how development and conservation interact are quite limited. We estimate forest impacts from combining development rights with land-use restrictions in the Peruvian Amazon. We analyze protected areas (PAs) - i.e. land-use restrictions - both without development rights, in strict PAs, and with limited development rights, in multiple-use PAs. We also evaluate logging rights in concessions with typical state restrictions, in uncertified concessions, and with additional 'sustainable forest management' restrictions, in certified concessions.

Globally, PAs are the leading policy to conserve forests by limiting economic activity. Yet restrictions often are not preferred by local communities or by market participants who seek forest products, crops, and other goods and services (Agrawal, Chhatre and Hardin, 2008). Consequently, PAs may not limit economic activities in the Peruvian Amazon's large and relatively inaccessible forests, where 'empty' PAs are subject to illegal logging invasions (Urrunaga et al., 2012; interviewees 1 \& 3, personal communication, 2015). However, Agrawal et al. (2008) found in settings of decentralized resource management that local stakeholders may act to lower invasions given their interest in forests. Conservation can adjust to such possibilities through PAs with involvement of key local stakeholders. Most analyses find that PAs reduce deforestation and that the impacts vary with PAs' types and locations (Joppa \& Pfaff, 2009, 2010; Pfaff, Amacher \& Sills, 2013; Pfaff et al., 2015 $\mathrm{a} \& \mathrm{~b})$.

Logging concessions are a leading form of decentralized forest management. Governments grant logging rights to private firms, subject to regulatory requirements (FAO, 2015b). The effect on forest is not clear. On the one hand, limited state monitoring and enforcement can 
permit forest losses in concessions to exceed the agreed levels (Finer, Jenkins, Sky, \& Pine, 2014; Sears \& Pinedo-Vasquez, 2011; Urrunaga et al., 2012). On the other hand, extraction rights create incentives for the firms to defend their forest assets by blocking other parties' illegal logging, which potentially reduces forest loss. In addition, the Forest Stewardship Council's (FSC) forest-management certification in theory rewards concessionaires for such reductions (more below in section 3.2). FSC audits intend to ensure that, at the least, certified concessions comply with all applicable laws (FSC, 2015b). While compliance also has costs for firms, certification may provide improvements in market access and prices for those firms that choose to restrict forest losses (Auld, Gulbrandsen \& McDermott, 2008).

Given multiple public-private interactions, it is unclear which policies will have the largest forest impacts (see Section 2). For PAs, both public and private actors affect PA siting and enforcement. Further, PA types and sizes influence how that siting and enforcement unfold. For concessions, firms clearly want to block illegal extraction by other private actors - but their compliance with forestry laws and their interactions with certifiers are less clear either theoretically and empirically. We hypothesize that the impact of certification depends upon firms' logging motivations and their capacities to defend forest assets. We shed empirical light on whether certification complements public governance and firms' defense of forest.

We estimate policies' impacts on 2000-2013 tree-cover loss compared to a baseline in 2000. Since the interventions we study were not randomly assigned, we use panel data with unit and year fixed effects to reduce bias. To the best of our knowledge, ours is one of the first quasi-experimental evaluations of FSC-forest-management-certification's effect on forest loss and the first for Peru. This study is also one of the first to address spatial and temporal 
sources of bias in estimates of impact for logging concessions, PAs, and forest-management certification. To evaluate FSC we compare certified concessions to uncertified concessions. To evaluate PAs and logging concessions, we compare uncertified concessions and PAs to forest controls outside of concessions and PAs. We study the Peruvian Amazon regions of Madre de Dios, Loreto and Ucayali (Figures 1 \& 2), using all of the logging concessions and PAs established after 2000 (thus extending Miranda et al., 2016), except private PAs.

We find that the PAs lower tree-cover loss on average for our entire study area - while PAs that allow for limited development save more forest than strict PAs, overall and by region. Thus, our results suggest that public-private interactions in both PA siting and enforcement influence forest impacts. Considering private enforcement by firms, for the same years and regions, we find that relative to the controls the uncertified concessions slightly reduce treecover loss in Madre de Dios, yet slightly increase loss in Ucayali. This variation in impacts by region may reflect public governance as well as the firms' motivations and capacities.

We find only within Madre de Dios that FSC certification lowers tree-cover loss, by about 1 percent in total for our entire study period, relative to the uncertified concessions. That we find an impact of FSC only in a region where uncertified concessions lower forest loss suggests that third-party certification efforts complement the enforcement efforts by firms. Taken together, our results certainly highlight the importance of forest governance, as well as potential gains from policies that combine development rights with land-use restrictions.

The rest of the paper is organized as follows. Section 2 discusses the interactions between public and multiple private actors in both siting and enforcement. Section 3 describes our 
empirical case, with background about both forestry in Peru and FSC's certification in Peru as well as facts about our data. Section 4 considers descriptive statistics and then presents our regression approaches featuring panel analyses that utilize fixed effects for concession or pixel units, as well as year effects. Section 5 presents all our results. Finally, Section 6 summarizes and interprets our results and then suggests some future research directions.

\section{Theoretical Insights on Impacts}

\subsection{Predicted Locations for Agriculture \& Conservation}

We consider first the 'canonical' predictions about the expected locations for agriculture which, in turn, have implications for expected locations of conservation policy such as PAs. Long ago, Von Thünen (1826) highlighted the importance of transport cost in determining agriculture's net benefits, which fall as transport costs rise with distances to urban markets. Considering a hypothetical city surrounded by forest land that could be used for farming, clearing for agriculture is predicted to extend outward from the city up to where the profits in agriculture fall below those from forest. Given that baseline prediction for a landscape, we ask where PAs will be located by the state. We expect greater private resistance where there is higher agricultural profit that would be lost due to the PA. Whether such costs of PAs are measured by land prices for state purchases or by political protest for state takings, costs are higher near the city. This appears to explain fairly well many big-picture patterns of PA locations, often found 'on rock and ice' or 'high and far' (e.g., Joppa \& Pfaff, 2009).

Yet different PA types can have different local benefits, which affect local net costs of PAs and, thereby, where PAs are politically feasible. For example, we see that multiple-use PAs, 
which allow smallholder extraction, are in locations with higher deforestation pressures (Nelson \& Chomitz, 2011; Joppa \& Pfaff, 2011; Pfaff et al., 2013). If such PAs are as well enforced as strict PAs (more just below), their locations imply potential for higher impact.

\subsection{Public \& Private Conservation Monitoring}

Monitoring and enforcement are key PA features distinct from siting. Public enforcement of PAs can vary by political unit (e.g., Pfaff et al., 2018 compare federal with state PAs in the Brazilian Amazon) and over time within a unit (e.g., Pfaff et al., 2017 show later impact from PAs in Mexico previously found to be 'paper parks'). For any regime, monitoring's intensity will be affected by costs, likely to be higher for larger PAs and further out on the agricultural frontier. Private actors may be willing to monitor multiple-use PAs that include provisions for their development benefits. With the resulting incentives, smallholders might want to help a public actor to exclude other private actors (Albers, 2010; Pfaff et al., 2013).

Summarizing, for PAs we can identify multiple forms of interactions in various decisions that affect conservation. This could invert the ranking of impacts by type of PA. If political economy were especially responsive to local benefits - affecting the siting of PAs - and if local forest users were capable of helping to exclude illegal loggers, we might observe that the multiple-use PAs have more impact than strict PAs. Yet neither condition always holds, as shown well by varied rankings of PA types across Amazonian states (Pfaff et al., 2015b).

\section{$\underline{2.3 \text { Private Concession Enforcement \& Interactions }}$}


Private logging concessions, the creation of which is a major development policy for forest, create unambiguous incentives for the logging firms who are granted the extraction rights (analogous incentives, in fact, to smallholders with rights in multiple-use PAs). Firms want to defend their access to the resources within concession boundaries, i.e., want to exclude others who harvest illegally. However, they may or may not be capable of such exclusion.

On the other hand, firms might extract more than agreed when the states granted the rights. Thus, impact also can depend upon public enforcement of concession terms, for which sites and sizes matter, since even if concessionaires exclude others extraction inside concessions could be very high. Yet forest management techniques also affect impact. Forest loss is less likely if logging is selective as has been typical in the Peruvian Amazon. Therefore, in sum, while based upon private rights to extract, concessions alone may raise or lower forest loss.

Next we consider interactions between the state agencies, private firms, and third parties involved in voluntary certifications of forest management. Certification could in principle substitute for and even go beyond the goals and means of the state, given market pressures if consumers are less willing to buy goods associated with forest loss. We hypothesize that certification complements public and private capacities and motivations to defend forest i.e., defense is a necessary condition for managing forest sustainably to please consumers.

\section{Empirical Setting: three regions in the Peruvian Amazon}

\section{$\underline{3.1 \text { Forests \& Forest Policies }}$}

Peru's tropical forests are the $2^{\text {nd }}$-largest in Latin America (Rainforest Alliance, 2014), and the $4^{\text {th }}$-largest globally, having over 70 million ha in 2011 (Ministerio del Ambiente, 2015). 
The government indicates that these forests protect: 97 percent of the freshwater supply; valuable timber species, such as cedar and mahogany; non-timber forest products; and biodiversity of ecological significance. Forests also contribute to social development, as the home to over one thousand indigenous communities - including over fifty ethnic groups (Ministerio del Ambiente \& Ministerio de Agricultura, 2011) described as "the poorest and most disenfranchised segment of the country's population" (Urrunaga et al., 2012).

Peru's Forestry and Wildlife Law No. 27308 categorizes around 70 percent of Peruvian forests as: i) production; ii) future management; iii) protected lands; iv) natural PAs; v) native and peasant communities; and vi) local forests (República del Perú, 2000). For the production areas, we compare certified with uncertified concessions. We also compare the uncertified concessions and PAs with controls, i.e. forests outside of concessions and PAs. Other forms of management surely affect these forests but we lack data (see Discussion).

Peru's Protected Area Act (Law No. 26834) classifies PAs as national, regional, or private. National Indirect Use PAs are strictly protected, allowing only non-manipulative research, tourism, and recreation in designated areas. They prohibit natural resource extraction and transformation of environments (República del Perú, 1997). National Direct Use PAs allow for resource management or extraction by local communities (República del Perú, 1997). National Reserved Zones are not PAs yet. They have a temporary status in the process of obtaining PA status (Solano, 2010), which can take 15 years. Reserved Zones permit even more types of extractive activity including for oil (interviewee 15, personal communication, June 2015). Regional PAs are managed by the regional governments and by municipalities. We exclude all private conservation areas, which are much smaller and were created later. 
In sum, we build on Miranda et al.'s (2016) pre-2000-PA evaluation by focusing on the 17 post-2000 National or Regional PAs in Madre de Dios, Ucayali and Loreto (Appendix 1).

Concessions of 5,000 - 40,000 ha were granted to firms or individuals, in 40-year contracts (República del Perú, 2000) for timber production and economic development. In total, 7.1 million ha (10 percent of Peru's forest) were designated for forestry in logging concessions in Madre de Dios, Loreto and Ucayali regions and the national total is about 8 million ha. Concessionaires must present a forest-management plan every five years and, annually, an operating plan indicating the subsections and volumes to be harvested for each key species (República del Perú, 2000). All wood extracted from the concessions is legally required to have a "Forest Transport Permit (GTF or Guía) which describes "the species and volume of the material and its place of origin" (Urrunaga et al., 2012). The regional forest authority is then supposed to check these official documents at different points in the transport system.

Yet evidence suggests illegal behaviors all along the production chains for logging outputs (Finer et al., 2014; Sears \& Pinedo-Vasquez, 2011; Urrunaga et al., 2012). Concessionaires may fail to report extraction from outside concessions or may falsify approval documents (Urrunaga et al., 2012). While the GTF should have information about authorized volumes by species, the forest authority has no way to verify the origin of wood that it is inspecting when in transport (Sears \& Pinedo-Vasquez, 2011, Urrunaga et al., 2012). Thus, regulators are "monitoring the product, emphasizing species and volumes, rather than processes such as logging practices and negotiation of access to timber" (Sears \& Pinedo-Vasquez, 2011). 
Peru's Supervisory Body of Forest Resources \& Wildlife (OSINFOR) monitors the logging activities in concessions, using field visits prior to verification (República del Perú, 2013a). Any supervisor could initiate an administrative process (PAU, in Spanish) to investigate a suspected irregularity, leading to a sanction and even to the cancellation of the concession (República del Perú, 2013b). Yet Finer et al. (2014) found that OSINFOR had never visited 36.3 percent of concessions, which is especially meaningful given that OSINFOR detected irregularities in the majority of the concessions where they had visited (Finer et al., 2014).

\subsection{FSC Certification of Logging Concessions}

We analyze private certification of sustainable forest management by FSC, one of the best known certification programs. It started in 1993 for "environmentally appropriate, socially beneficial, and economically viable management of the world's forests" (FSC, 2015a). By February 2018, over 1,547 FSC certificates were active, covering 199.9 million hectares of forest in 85 countries (FSC, 2018). FSC certification is said to be "rigorous, transparent and participatory certification" (Hale \& Held, 2011), though its ability to produce forest benefit has been evaluated only rarely - and even less often rigorously so (see Counsell \& Loraas, 2002; Nebel, Quevedo, Jacobsen \& Helles, 2005; and more recently see Miteva, Loucks \& Pattanayak, 2015; Burivalova, Hua, Koh, Garcia \& Putz, 2017; Blackman, Goff \& RiveraPlanter, 2018; Rana \& Sills, 2018; and Villalobos, Coria \&, Nordén, 2018).

During 2006-2013, 34 logging concessions received a forest-management certification in Loreto, Madre de Dios or Ucayali (FSC Peru, 2017). By February 2018, in total 805,831 ha were under FSC certification (FSC Peru, 2017), yet how the FSC certification arose varies 
by region and firm. In Madre de Dios, technical and financial help from donors and NGOs supported the FSC certifications (interviewee 6, personal communication, June 2014). This region has the largest area under FSC certification, as well as the majority of certificates in our study area during 2006-2013 (20 of the 34 certificates). As external support, the Global Forest Trade Network (GFTN) of the World Wildlife Fund offered companies technical and strategic aid to help comply with - and, thus, raise ongoing achievement of - FSC's forestmanagement certification within logging concessions (World Wildlife Fund, 2015).

Such support can help firms to deal with costs of certification. FSC compliance can raise labor costs, as employees should be on payroll and receive health benefits (interviewee 5, personal communication, August 2014). Companies do monitoring - including creating and auditing inventories- and they hire consultants. Overall, firms clearly must incur costs in order to obtain FSC certification (interviewee 1, personal communication, August 2014).

On the other hand, firms can also obtain benefits. FSC certification may increase access to: i) export markets that prohibit illegally sourced timber; ii) price premia; iii) government incentives; iv) operational efficiencies; and v) NGO funding (Blackman, Raimondi, \& Cubbage, 2014; Breukink, Levin, \& Mo, 2015). Legal timber sources are ever more critical, given that the United States' Lacey Act and the European Union's FLEGT Action Plan require verification of timber's origin (European Forest Institute, 2014; Urrunaga et al., 2012). Thus, if these initiatives were strictly enforced and certification was well audited, then in principle the export and, in turn, the sourcing of illegal timber could be reduced. More generally, certification and laws that empower it could improve forest outcomes. 
Yet with poor enforcement, FSC certification can have negative net forest impact, including via spillovers to other locations. Poor monitoring may allow firms enhanced market access and scale without improving practices (Finer et al., 2014; Sears \& Pinedo-Vasquez, 2011; Urrunaga et al., 2012). A firm could log one FSC-certified concession sustainably but then use the FSC label for their outputs from forests not managed according to FSC's standards.

\section{$\underline{3.3 \text { Data }}$}

\subsubsection{Tree-Cover Loss}

We obtained annual tree-cover loss data at 30-meter resolution from the Global Forest Change data (Hansen et al., 2013) for three Peruvian Amazon regions (Madre de Dios, Loreto, Ucayali) during 2000-2013. We define 'forest' as a stand with at least 50 percent tree cover. (We note in addition that when we used 30 percent, as others sometimes have, that made no difference within our analyses.) Annual tree-cover maps were derived within ArcMap version 10.2 (ESRI, 2014). Subsequently, all the geospatial data referred to below were compiled, produced and harmonized by projection and resolution in ArcMap.

\subsubsection{Concessions}

We obtained data on logging concessions and FSC from WWF Peru in September 2014. They gathered, revised and updated data on concession boundaries from OSINFOR - plus concession characteristics from the Ministry of Environment (MINAM) and the Ministry of Agriculture (MINAG) including: contract number; concessionaire name; concession's legal status; date of creation; harvesting volume; logging cycle; description of harvesting system 
(the technology and the methods used); and annual planned investments. However, except for the first four variables, these variables were incomplete for most logging concessions.

WWF Peru also gathered extra information about FSC from FSC Peru and MINAG, which for any certified concession includes: FSC license; FSC code; type of FSC certificate; and certification status. Since FSC publishes information about all of these certificates online, we added the certificate start dates and, if applicable, the expiration and suspension dates.

\subsubsection{Protected Areas}

We obtained data on all protected areas' boundaries and characteristics from WWF Peru in July 2015. That data included name, category, type, and start date. WWF Peru obtained the original information from the National Service of Natural Protected Areas (SERNANP).

\subsubsection{Site Characteristics}

We use characteristics (Appendix 2) that affect the probabilities of both tree-cover loss and our treatments (uncertified concessions, certification of concessions, and PAs). For market access, we use distances to cities, roads, and navigable rivers from MINAM (noting that we are not yet able to control for any key characteristics of the target markets). Oliveira et al. (2007) note: “75 percent of the total Peruvian Amazon forest damage [between 1999 and 2005], including 66 percent of disturbances and 83 percent of deforestation, was detected within a $20 \mathrm{~km}$ distance from the nearest roads". Distance to rivers is important in Ucayali and Loreto, as logs are transported by rivers when the roads are impassable during the rainy season (interviewees 8 and 12, personal communication, June 2014). Distance to roads can 
be the relevant indicator of market access for Madre de Dios, as logs are transported mainly by road there (interviewees 8 and 12, personal communication, June 2014). Our biophysical characteristics are elevation, slope, and 1950-2000 average temperature and precipitation in the WorldClim (Hijmans, Cameron, Parra, Jones \& Jarvis, 2005) and CGIAR-CSI (Jarvis, Reuter, Nelson \& Guevara, 2008) global data sets. They all affect profits within agriculture, a land-use alternative to forest (noted in Section 2.1). Following extensive evidence within the related literature (e.g., Andam, Ferraro, Pfaff, Sanchez-Azofeifa \& Robalino, 2008), we conjecture that the probability of deforestation rises with the profitability of agriculture.

\subsubsection{Data Units}

We compiled a panel data set at the concession level. A concession's entire area is included in measuring its outcome: forest loss in a given year, as a fraction of the forest in 2000. Our data include one forest observation per year, for each of the concessions - and, thus, 6,825 concession-year observations to compare losses in certified versus uncertified concessions.

We also compiled a panel data set at a pixel level (30x30m), inside and outside concessions with 398,006 pixels over 55.4 million ha of forest. That implies a sample density of roughly 1 pixel for every $100 \mathrm{ha}\left(1 \mathrm{~km}^{2}\right)$. With one observation for each pixel for 13 years, we have 5.2 million pixel-year observations in total. Only in the pixel data do we have information about forests outside concessions. Those data form the basis for analyses involving control forests to evaluate uncertified concessions and PAs. We do not use them to test certification because, without a very high pixel density, we have few pixels within certified areas - thus, we are concerned that we would not appropriately represent them in inferences on impacts. 


\section{Methods: statistics \& panel regressions}

\section{$\underline{4.1 \text { Descriptive Statistics }}$}

TABLE 1

Number of Forested (in 2000) Pixels in Our Random Sample, by Region and Treatment (Type \& Timing).

\begin{tabular}{|c|c|c|c|c|c|c|c|c|}
\hline & \multicolumn{2}{|c|}{ All Regions } & \multicolumn{2}{|c|}{ Madre de Dios } & \multicolumn{2}{|c|}{ Loreto } & \multicolumn{2}{|c|}{ Ucayali } \\
\hline & $\begin{array}{r}\text { Treated } \\
<2000\end{array}$ & $\begin{array}{l}\text { Treated } \\
>=2000\end{array}$ & $\begin{array}{l}\text { Treated } \\
<2000\end{array}$ & $\begin{array}{l}\text { Treated } \\
\geq 2000\end{array}$ & $\begin{array}{r}\text { Treated } \\
<2000\end{array}$ & $\begin{array}{l}\text { Treated } \\
\geq 2000\end{array}$ & $\begin{array}{r}\text { Treated } \\
<2000\end{array}$ & $\begin{array}{l}\text { Treated } \\
\geq 2000\end{array}$ \\
\hline Controls & -------- & 238,529 & ------ & 23,417 & ------ & 179,466 & ------ & 35,646 \\
\hline $\begin{array}{l}\text { Concession } \\
\text { Uncertified }\end{array}$ & 1,206 & 42,840 & 167 & 5,759 & 657 & 18,652 & 382 & 18,429 \\
\hline $\begin{array}{l}\text { Concession } \\
\text { Certified }\end{array}$ & 341 & 6,720 & ------ & 3,452 & 341 & 582 & ------ & 2,686 \\
\hline $\begin{array}{l}\text { National PA } \\
\text { Indirect Use }\end{array}$ & 13,011 & 25,222 & 13,010 & 9,051 & 0 & 6,512 & 1 & 9,659 \\
\hline $\begin{array}{l}\text { National PA } \\
\text { Direct Use }\end{array}$ & 15,355 & 18,899 & 0 & 4,962 & 15,355 & 10,929 & 0 & 3,008 \\
\hline $\begin{array}{l}\text { National PA } \\
\text { Reserved }\end{array}$ & 2,158 & 16,666 & 0 & 0 & 2,158 & 13,078 & 0 & 3,588 \\
\hline Regional PA & 0 & 17,059 & 0 & 0 & 0 & 16,199 & 0 & 860 \\
\hline TOTALS & 32,071 & 365,935 & 13,177 & 46,641 & 18,511 & 245,418 & 383 & 73,876 \\
\hline
\end{tabular}

Note: "Forest" $=$ tree cover $>50 \%$. Private PA points dropped. Both points hold for all tables below. Source: Authors' calculations with data from Global Forest Change, MINAM, MINAG, and SERNANP.

Table 1 compares interventions, overall and by region, by number of forest pixels in 2000 and by timing. In the second and third rows for All Regions, it is clear that almost all of the forest in concessions is within those that started after 2000. That supports a panel analysis 
of post-2000 interventions using Global Forest Change data for tree-cover loss. In contrast, many PAs were created before 2000 - below half for the whole study area but 58 percent of National Direct Use PAs in Loreto and 59 percent of National Indirect Use PAs in Madre de Dios. As the earlier PAs do not shift their PA status after 2000, we do not include them in our panel analyses (yet we highlight that they are the focus of Miranda et al., 2016).

There are regional differences. Madre de Dios has zero Regional PAs or National Reserved Zones. Loreto has the smallest National Indirect Use area. Madre de Dios and Ucayali have higher fractions with some treatment, at about half, than Loreto, at about a quarter - yet the latter has more treated points as it is larger. Madre de Dios has the highest certified area and highest share (20 of 91 concessions certified). Ucayali has the largest FSC concession, yet only 8 of 179 concessions certified, and Loreto has only 6 of 255 concessions certified.

\subsubsection{Average Tree-Cover Loss}

Table $2 \mathrm{~A}$ presents the simplest possible raw differences in the rates of tree-cover loss between our control forests and the forest areas that received each of our treatments without any effort to control for ways in which the treated forested lands may be different. The negative values are indicating lower rates of tree-cover loss for areas with treatments.

The top rows show concessions, certified or not, have lower tree-cover losses than controls. In a context of illegal timber production, it would be of interest if enforcement by the firms, with incentives based on extraction rights, could 'substitute for' limited public monitoring. 
Table 2A's final four rows consider PA types. They have lower tree-cover loss than controls and - comparing to above - on average lower than the concessions as well. Yet Table 2A's loss comparisons lack some critical information required to think about treatment impacts. Implicit in Table 2A is that forest is considered as treated (or not) throughout our period, while most of the concessions and many of the PAs were active in only some of the years. In addition, treated lands are likely to differ in characteristics that affect the probability of tree-cover loss. Thus, for better comparisons, we have to control for both space and time.

TABLE 2A

Simple Differences in Tree-Cover Loss Rates (2000-2013), by region and treatment type.

\begin{tabular}{|c|c|c|c|c|}
\hline & All & Madre de Dios & Loreto & Ucayali \\
\hline $\begin{array}{l}\text { Uncertified Concessions } \\
\text { minus Controls }\end{array}$ & $-1.46 \% * *$ & $-2.44 \% * *$ & $-0.99 \% * *$ & $-4.39 \% * *$ \\
\hline $\begin{array}{l}\text { Certified Concessions } \\
\text { minus Controls }\end{array}$ & $-1.42 \% * *$ & $-3.01 \% * *$ & $-0.60 \%$ & $-3.95 \% * *$ \\
\hline $\begin{array}{c}\text { National Indirect Use PA } \\
\text { minus Controls }\end{array}$ & $-1.93 \% * *$ & $-2.90 \% * *$ & $-1.15 \% * *$ & $-5.31 \% * *$ \\
\hline $\begin{array}{l}\text { National Direct Use PA } \\
\text { minus Controls }\end{array}$ & $-1.68 \% * *$ & $-2.88 \% * *$ & $-0.96 \% * *$ & $-4.20 \% * *$ \\
\hline $\begin{array}{l}\text { National Reserved PA } \\
\text { minus Controls }\end{array}$ & $-2.04 \% * *$ & ---- & $-1.28 \% * *$ & $-5.22 \% * *$ \\
\hline $\begin{array}{l}\text { Regional PA } \\
\text { minus Controls }\end{array}$ & $-1.95 \% * *$ & ---- & $-1.31 \% * *$ & $-2.57 \% * *$ \\
\hline
\end{tabular}

Note: $* \mathrm{p}<0.05 ; * * \mathrm{p}<0.01$. Source: Authors' calculations using data from Global Forest Change, MINAM, MINAG, and SERNANP.

\subsubsection{Treatment Timing \& Tree-Cover Loss}


Table $2 \mathrm{~B}$ adds information based on the year within which these interventions were active. It aggregates the PA types and provides total loss rates before and while they were active. Seemingly in contradiction to the spatial comparisons above, the tree-cover-loss rates in ever-PA areas are higher when the PAs were active than before they were active. That highlights the need to control for time, as pressures upon forests could rise over time.

Similarly, we distinguish when any given concession or any FSC certificate were active.

For the non-FSC concessions, tree-cover loss when the concession is active is greater than before the concession starts - which would make sense given the purpose of a concession. Further, tree-cover loss after the concession ends (if applicable) also is higher than before it is active. Concession operation - e.g., creating logging roads - may raise later loss. Alternatively, loss rates may be trending up over time across the area.

TABLE 2B

Absolute Tree-Cover Loss Rates (2000-2013), by region and timing relative to different treatment types.

\begin{tabular}{|c|c|c|c|c|c|c|c|c|c|c|}
\hline & \multirow[t]{2}{*}{ Controls } & \multicolumn{2}{|c|}{ Ever In A PA } & \multicolumn{3}{|c|}{ In Concession, Not FSC } & \multicolumn{4}{|c|}{ In A Concession That Is FSC At Some Point } \\
\hline & & $\begin{array}{l}\text { Before } \\
\text { Active }\end{array}$ & $\begin{array}{c}\text { While } \\
\text { Active }\end{array}$ & $\begin{array}{l}\text { Before } \\
\text { Active }\end{array}$ & $\begin{array}{c}\text { While } \\
\text { Active }\end{array}$ & $\begin{array}{c}\text { After } \\
\text { Active }\end{array}$ & $\begin{array}{l}<\text { Conc. } \\
<\text { FSCC }\end{array}$ & $\begin{array}{l}=\text { Conc } . \\
<\text { FSCC }\end{array}$ & $\begin{array}{l}=\text { Conc } . \\
=F S C C\end{array}$ & $\begin{array}{l}=\text { Conc } . \\
>\text { FSCC }\end{array}$ \\
\hline Madre de Dios & $3.19 \%$ & $0.00 \%$ & $0.28 \%$ & $0.03 \%$ & $0.59 \%$ & $0.12 \%$ & $0.00 \%$ & $0.06 \%$ & $0.12 \%$ & $0.00 \%$ \\
\hline Loreto & $1.36 \%$ & $0.02 \%$ & $0.20 \%$ & $0.04 \%$ & $0.24 \%$ & $0.10 \%$ & $0.00 \%$ & $0.43 \%$ & $0.33 \%$ & $0.00 \%$ \\
\hline Ucayali & $5.36 \%$ & $0.10 \%$ & $0.30 \%$ & $0.03 \%$ & $0.86 \%$ & $0.14 \%$ & $0.04 \%$ & $0.56 \%$ & $0.74 \%$ & $0.07 \%$ \\
\hline All Regions & $2.14 \%$ & $0.03 \%$ & $0.24 \%$ & $0.03 \%$ & $0.54 \%$ & $0.12 \%$ & $0.01 \%$ & $0.30 \%$ & $0.38 \%$ & $0.03 \%$ \\
\hline
\end{tabular}

Source: Authors' calculations using data from Global Forest Change, MINAM, MINAG, and SERNANP.

\subsubsection{Treated-Site Characteristics}


Tables 3A - 3D show that regions and interventions differ in forest-relevant characteristics.

Table 3A provides averages for seven characteristics for all of the pixels in each treatment.

Tables 3B - 3D provide road, river, and city distances for subsets of each treatment's pixels.

Consistent with prior analyses (Joppa \& Pfaff, 2009; Pfaff et al., 2013), Table 3A's top row shows that the National Direct Use PAs ("Direct"), which are one form of multiple-use PA, are closer to roads than are the stricter PAs ("Indirect") - and in fact are as close to roads as concessions and controls. Its third row shows that concessions are closer to the capital than are National PAs. Biophysical characteristics vary less (so are not a focus in Tables 3B-D).

\section{TABLE 3A}

Averages for all observed characteristics relevant for rates of deforestation, by treatment.

\begin{tabular}{|l|r|rr|rrr|r|}
\cline { 2 - 7 } & Controls & Non-FSCC & FSCC & Indirect & Direct & Reserved & Regional \\
\hline \hline Distance to road $(\mathrm{km})$ & 47 & 55 & 41 & 86 & 46 & 86 & 59 \\
Distance to river $(\mathrm{km})$ & 19 & 22 & 25 & 17 & 22 & 23 & 34 \\
Distance to capital $(\mathrm{km})$ & 192 & 169 & 157 & 235 & 211 & 192 & 127 \\
\hline Elevation $(\mathrm{m})$ & 1,460 & 1,462 & 1,450 & 1,455 & 1,451 & 1,448 & 1,468 \\
Slope $($ degrees) & 9.72 & 9.75 & 9.80 & 9.69 & 9.70 & 9.63 & 9.73 \\
Temperature $\left({ }^{\circ} \mathrm{C}\right)$ & 19.20 & 19.21 & 19.25 & 19.24 & 19.25 & 19.24 & 19.14 \\
Precipitation $(\mathrm{mm})$ & 1,562 & 1,566 & 1,560 & 1,569 & 1,568 & 1,566 & 1,555 \\
\hline
\end{tabular}

Tables 3B, 3C and 3D show mean distances to roads, rivers, and capital of the certified and uncertified concessions and all PAs - by region and treatment period (before or after 2000). Table 3B's top two rows show the few pre-2000 concessions - all in Loreto - are closer to roads than post-2000 concessions. Its third row shows Indirect Use PAs - all in Madre de Dios and Ucayali - follow this pattern, though Direct Use PAs do not follow this pattern. Table 3C suggests that there are fewer such differences in terms of the distances to rivers. However, Table 3D echoes the time patterns within Table 3B for distances to the capital. 
TABLE 3B

Average road distance $(\mathrm{km})$, by region and timing of national policy treatments

\begin{tabular}{|c|c|c|c|c|c|c|c|c|}
\hline & \multicolumn{2}{|c|}{ All Regions } & \multicolumn{2}{|c|}{ Madre de Dios } & \multicolumn{2}{|c|}{ Loreto } & \multicolumn{2}{|c|}{ Ucayali } \\
\hline & $\begin{array}{r}\text { Treated } \\
<2000\end{array}$ & $\begin{array}{r}\text { Treated } \\
\geq 2000\end{array}$ & $\begin{array}{r}\text { Treated } \\
<2000\end{array}$ & $\begin{array}{r}\text { Treated } \\
\geq 2000\end{array}$ & $\begin{array}{r}\text { Treated } \\
<2000\end{array}$ & $\begin{array}{r}\text { Treated } \\
\geq 2000\end{array}$ & $\begin{array}{r}\text { Treated } \\
<2000\end{array}$ & $\begin{array}{r}\text { Treated } \\
\geq 2000\end{array}$ \\
\hline NonFSCC & 32.6 & 55.7 & 9.9 & 50.0 & 38.5 & 73.3 & 32.4 & 39.7 \\
\hline FSCC & 22.0 & 41.6 & ----- & 48.3 & 22.0 & 39.4 & ------ & 33.4 \\
\hline NatPA Indirect Use & 62.9 & 97.2 & 62.9 & 122.0 & ------ & 33.9 & 80.2 & 116.7 \\
\hline NatPA Direct Use & 47.5 & 38.6 & ------ & 25.7 & 54.1 & 41.6 & ------ & 48.6 \\
\hline NatPA Reserved & 53.6 & 90.7 & ------ & ------ & 53.6 & 104.3 & ------ & 41.3 \\
\hline Regional PA & ------ & 58.6 & ------ & ------ & ------ & 60.8 & ------ & 17.6 \\
\hline
\end{tabular}

Source: Authors' calculations using data from Global Forest Change, MINAM, MINAG, and SERNANP.

TABLE 3C

Average river distance $(\mathbf{k m})$, by region and timing of national policy treatments.

\begin{tabular}{|c|c|c|c|c|c|c|c|c|}
\hline & \multicolumn{2}{|c|}{ All Regions } & \multicolumn{2}{|c|}{ Madre de Dios } & \multicolumn{2}{|c|}{ Loreto } & \multicolumn{2}{|c|}{ Ucayali } \\
\hline & $\begin{array}{r}\text { Treated } \\
<2000\end{array}$ & $\begin{array}{r}\text { Treated } \\
\geq 2000\end{array}$ & $\begin{array}{r}\text { Treated } \\
<2000\end{array}$ & $\begin{array}{r}\text { Treated } \\
\geq 2000\end{array}$ & $\begin{array}{r}\text { Treated } \\
<2000\end{array}$ & $\begin{array}{r}\text { Treated } \\
\geq 2000\end{array}$ & $\begin{array}{r}\text { Treated } \\
<2000\end{array}$ & $\begin{array}{r}\text { Treated } \\
\geq 2000\end{array}$ \\
\hline Non-FSCC & 20.0 & 22.1 & 14.6 & 17.7 & 23.9 & 24.4 & 15.7 & 21.1 \\
\hline FSCC & 24.2 & 25.2 & ----- & 29.1 & 24.2 & 15.9 & ------ & 22.1 \\
\hline NatPA Indirect Use & 14.6 & 19.0 & 14.6 & 21.2 & ----- & 16.7 & 13.9 & 18.4 \\
\hline NatPA Direct Use & 20.8 & 23.5 & ----- & 17.3 & 20.8 & 28.2 & ----- & 16.5 \\
\hline NatPA Reserved & 23.2 & 23.3 & ----- & ----- & 23.2 & 18.9 & ----- & 39.5 \\
\hline Regional PA & ----- & 34.2 & ----- & ----- & ------ & 35.9 & ----- & 3.3 \\
\hline
\end{tabular}

Source: Authors' calculations using data from Global Forest Change, MINAM, MINAG, and SERNANP.

TABLE 3D

Average capital city distance $(\mathbf{k m})$, by region and timing of national policy treatments.

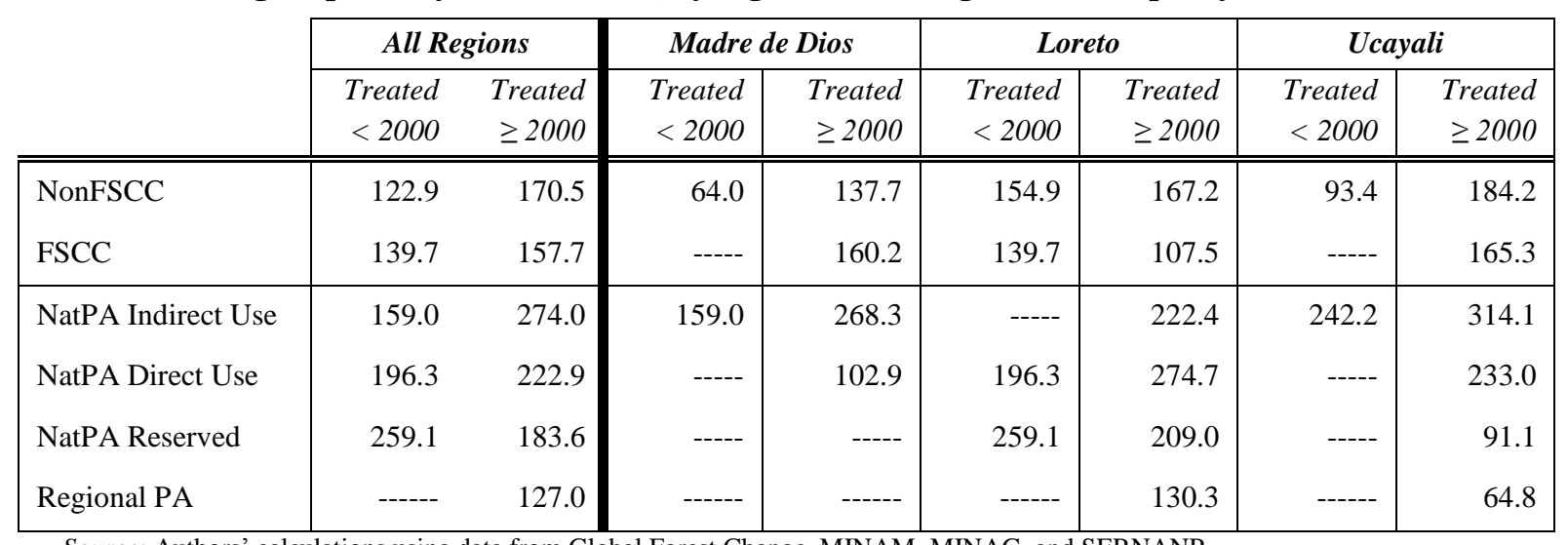

Source: Authors' calculations using data from Global Forest Change, MINAM, MINAG, and SERNANP. 


\subsection{Panel Regression: concessions units}

As treatments are not randomly assigned, to reduce bias we control for spatial and temporal influences using spatiotemporal data in panel analysis. Concerning temporal influences, this methodology subtracts out average time trends, such that impacts of shifts in policies across time are not confounded by other trends. For spatial influences, this method compares each site in a given year to its own average across all the years (effectively, then, comparing later years to earlier years for the same place). Therefore, every fixed characteristic of a site is held constant within comparisons, including characteristics we do not measure. Consequently, fixed spatial differences across locations, such as slope or proximity to cities, do not matter. Panel impact estimates reflect how treated sites' changes in each site after versus before treatment - compare to the time changes for the untreated sites for the same time periods.

For each treated concession, we compare the tree-cover loss rate for certified years with the loss rate for uncertified years. If certification starts in 2006 , we subtract annual tree-cover loss after 2006 from before. Here, as certifications start after 2005 and mostly remain active (few terminations or expirations), the certified years are the later years of our study period. Since forest pressure was higher in later years, temporal correlation of certification and loss can make it look like certification causes loss. That is fixed by subtracting average trends.

Following the above logic, Equation 1 is our panel specification with fixed and year effects

- which we estimate for the whole study area, as well as separately for each of the regions:

$$
L_{i t}=\beta_{0}+\beta_{1} F_{i t}+\beta_{2} C_{i t}+\alpha_{i}+\lambda_{t}+\varepsilon_{i t}
$$


where $L_{i t}=$ percent tree-cover loss in concession $i$ in year $t ; C_{i t}=1$ if concession $i$ active in year $t ; F_{i t}=1$ if concession $i$ had active certification in year $t ; \alpha_{i}=$ concession fixed effects; $\lambda_{t}=$ year effects; and $\varepsilon_{i t}$ a random error. We cluster standard errors at the concession level.

Concessions vary in size. Thus, results for 'the average concession' (same weight on each unit) could differ from results for 'the average hectare' in concessions (weighting by area). Our default panel weights each concession equally, as we wanted to focus on results for the average across the decision units. In robustness checks, weighting did not shift conclusions.

\subsection{Panel Regression: pixels units, with matching by treatment for greater similarity}

We used a similar method for pixel data units (though weighting by area is irrelevant), and equation 2 is our pixel-units panel specification, with pixel fixed effects plus year effects:

$$
L_{i t}=\beta_{0}+\beta_{1} I_{i t}+\alpha_{i}+\lambda_{t}+\varepsilon_{i t}
$$

similar to (1) except now $i$ refers to a pixel, so $L_{i t}=1$ if the forested pixel was deforested in year $t$ but 0 if it was $\operatorname{not}^{3}$ (and missing after deforestation); $I_{i t}=1$ if the intervention for site $i$ (a concession or a PA) was active in the year $t$. We cluster standard errors at a pixel level.

We emphasize that the panel regression is a form of 'difference-in-difference estimation': the difference post-treatment versus pre-treatment for the treated units (the first difference) is compared with the same difference computed for the control units (second difference). That second difference provides a form of empirical guess about what would have occurred

\footnotetext{
${ }^{3}$ For this binary outcome, we explored conditional fixed effects logistic regression but we could not use this model because deforestation is too rare: $L_{i t}=1$ in less than $1 \%$ of the cases (pixel-year observations). To the best of our knowledge, there are no commands for rare binary events using panel data allowing fixed effects.
} 
in treated areas without treatment, i.e., a counterfactual. Treatment impacts are identified if the time change in treated units without treatment would have been the same as in controls.

Numerous pixels allow improved panel analyses. To increase the validity of assuming that without treatments the treated and control pixels would have had the same trends over time, we endeavor to find the controls that have the most similar observable characteristics to the treated units (see Section 3.3 and Appendix 2 for the data that we use for making similarity judgments, as well as the Discussion section for some data that we do and do not have). After matching, we run our panel specification using treated units and matched controls.

Appendix 3 shows the gains in similarity from different types of matching: propensity score matching (PSM), with and without replacement, and covariate matching (final 3 columns). Biophysical characteristics vary so little in the Peruvian Amazon that we did not use them to select the most similar controls. We rely on the final column, nearest neighbor covariate matching with replacement, always doing the matching within the same region, because it yielded the best covariate balance, as seen across the rows for each treatment and variable.

PSM starts with a treatment regression then matches pixels on the basis of their predicted probabilities of treatment. Comparing PSM columns shows some gain from 'replacement': even if a control pixel is chosen as the best fit for one treated pixel, it is replaced in the pool to find the best fit for other treated pixels. Thus, we also used replacement for the covariate matching. For each treated pixel, covariate matching computes the Mahalanobis distance within the space of the observed characteristics - to each control pixel. We matched to the 
single control pixel closest to each treated pixel (for more information see StataCorp, 2013).

\section{Results}

\subsection{Protected Areas vs. Control Forests}

Table 4's upper half summarizes our panel impact estimates for all of our PA interventions. There is significant variation in impact across the intervention regions and the types of PAs.

\subsubsection{National Indirect Use PAs (strict)}

Strikingly, for Madre de Dios, strict PAs have more tree-cover loss than the control forests. That is consistent with a concern that 'empty' PAs could be susceptible to illegal invasions. However, that does not hold for Ucayali, where there is no significant effect of these PAs. Loreto displays the opposite, lower tree-cover loss than control pixels, but the coefficient is not statistically significant, given a larger standard error. Yet Loreto drives a statistically significant loss reduction from Indirect Use PAs across the whole study area: a quite small loss reduction of one quarter of one percent for the entire period (half a percent for Loreto).

\subsubsection{National Direct Use PAs (multiple-use)}

Multiple-use PAs significantly lower tree-cover loss in each region. Average loss reduction for the whole study area is over 1 percent over the entire period. Loreto's effect is smaller and applies to two-thirds of the observations in our study area, while the impacts in Madre de Dios and Ucayali are far larger, at about 6 percent lower tree-cover loss for the period.

\subsubsection{National Reserved Zones (still in the process of becoming PAs)}


Reserved Zones have low average impact, reducing tree-cover loss by one third of a percent for the whole period. The small average impact is driven by one region whose impact is not statistically significant - Ucayali - given fewer observations and the higher standard error. Ucayali's impact coefficient is close to 2 percent lower tree-cover loss for the entire period.

\subsubsection{Regional PAs (managed by lower levels of government)}

Regional PAs lower tree-cover loss rates by around 2 percent, on average, over the entire period for the whole study area. Most of these particular conservation interventions are located in Loreto, where they reduce loss by 1 percent relative to the control forests for 2000-2013. However, the very few Regional PAs in Ucayali provide quite another story, appearing here to reduce tree-cover loss, on average, by an enormous 3 percent per year.

\section{$\underline{5.2 \text { Uncertified Concessions vs. Control Forests }}$}

Table 4's panel analysis of pixels found no impact of uncertified concessions, on average. Yet results for regions show that the average impact masks differences in regions' impacts. In Madre de Dios, uncertified concessions reduce tree-cover loss relative to control forests by $\sim 1$ percent for 2000-2013. This effect of concessions, versus control forests, is the same magnitude as the impact of certifications relative to the uncertified concessions (see below). At least in this governance context, private enforcement perhaps functions to reduce losses.

However, the opposite impact is found for Ucayali. Table 4 suggests that the private rights raised tree-cover loss. Of the same magnitude as the loss reduction in Madre de Dios, for Ucayali uncertified concessions have more tree-cover loss than control forests. This result is supported by Table 5's panel analysis done using concessions as the unit of analysis. 
TABLE 4 Pixel-level Data Panel Examining Deforestation during 2001-2013 for Post-2000 Interventions

\begin{tabular}{|c|c|c|c|c|}
\hline & & & & \\
\hline & $A l l$ & Madre de Dios & Loreto & Ucayali \\
\hline $\begin{array}{l}\text { NatPA Indirect Use } \\
\text { (fixed \& year effects) }\end{array}$ & $\begin{array}{l}-0.0002 \\
(0.0001)^{* * *}\end{array}$ & $\begin{array}{l}0.0001 \\
(0.0000)^{* * *}\end{array}$ & $\begin{array}{l}-0.0004 \\
(0.0004)\end{array}$ & $\begin{array}{l}-0.0001 \\
(0.0001)\end{array}$ \\
\hline $\mathrm{N}$ & 391,395 & 127,796 & 121,391 & 142,208 \\
\hline $\begin{array}{r}\text { NatPA Direct Use } \\
\text { (fixed \& year effects) }\end{array}$ & $\begin{array}{l}-0.0012 \\
(0.0001)^{* * * *}\end{array}$ & $\begin{array}{l}-0.0050 \\
(0.0014) * *\end{array}$ & $\begin{array}{l}-0.0003 \\
(0.0001)^{* *}\end{array}$ & $\begin{array}{l}-0.0049 \\
(0.0006) * * *\end{array}$ \\
\hline $\mathrm{N}$ & 294,903 & 45,351 & 199,169 & 50,383 \\
\hline $\begin{array}{l}\text { NatPA Reserved } \\
\text { (fixed \& year effects) }\end{array}$ & $\begin{array}{l}-0.0003 \\
(0.0001)^{* * * *}\end{array}$ & & $\begin{array}{l}-0.0000 \\
(0.0001)\end{array}$ & $\begin{array}{l}-0.0013 \\
(0.0008)\end{array}$ \\
\hline $\mathrm{N}$ & 279,317 & & 207,215 & 51,372 \\
\hline $\begin{array}{l}\text { Regional PA } \\
\quad \text { (fixed \& year effects) }\end{array}$ & $\begin{array}{l}-0.0016 \\
(0.0003)^{* * * *}\end{array}$ & & $\begin{array}{l}-0.0007 \\
(0.0002)^{* * *}\end{array}$ & $\begin{array}{l}-0.0301 \\
(0.0066) * * *\end{array}$ \\
\hline $\mathrm{N}$ & 244,575 & & 227,833 & 13,728 \\
\hline $\begin{array}{l}\text { Uncertified } \\
\text { Concession }\end{array}$ & $\begin{array}{c}0.0001 \\
(0.0001)\end{array}$ & $\begin{array}{l}-0.0007 \\
(0.0004)^{*}\end{array}$ & $\begin{array}{l}-0.0001 \\
(0.0001)\end{array}$ & $\begin{array}{l}0.0008 \\
(0.0002)^{* * *}\end{array}$ \\
\hline Year 2002 & $\begin{array}{l}0.0002 \\
(0.0001) * * *\end{array}$ & $\begin{array}{l}0.0004 \\
(0.0002)^{*}\end{array}$ & $\begin{array}{l}0.0001 \\
(0.0001)^{* *}\end{array}$ & $\begin{array}{c}0.0000 \\
(0.0002)\end{array}$ \\
\hline Year 2003 & $\begin{array}{l}0.0003 \\
(0.0001)^{* * *}\end{array}$ & $\begin{array}{l}0.0011 \\
(0.0004)^{* *}\end{array}$ & $\begin{array}{l}0.0001 \\
(0.0001)^{* *}\end{array}$ & $\begin{array}{l}-0.0001 \\
(0.0002)\end{array}$ \\
\hline Year 2004 & $\begin{array}{l}0.0005 \\
(0.0001)^{* * *}\end{array}$ & $\begin{array}{l}0.0014 \\
(0.0005)^{* * *}\end{array}$ & $\begin{array}{l}0.0004 \\
(0.0001)^{* * *}\end{array}$ & $\begin{array}{l}0.0001 \\
(0.0002)\end{array}$ \\
\hline Year 2005 & $\begin{array}{l}0.0007 \\
(0.0001)^{* * *}\end{array}$ & $\begin{array}{l}0.0016 \\
(0.0005)^{* * *}\end{array}$ & $\begin{array}{l}0.0005 \\
(0.0001)^{* * *}\end{array}$ & $\begin{array}{l}0.0005 \\
(0.0003)^{*}\end{array}$ \\
\hline Year 2006 & $\begin{array}{l}0.0006 \\
(0.0001)^{* * *}\end{array}$ & $\begin{array}{l}0.0011 \\
(0.0004)^{* * *}\end{array}$ & $\begin{array}{l}0.0005 \\
(0.0001)^{* * * *}\end{array}$ & $\begin{array}{c}0.0002 \\
(0.0002)\end{array}$ \\
\hline Year 2007 & $\begin{array}{l}0.0007 \\
(0.0001)^{* * *}\end{array}$ & $\begin{array}{l}0.0016 \\
(0.0004)^{* * *}\end{array}$ & $\begin{array}{l}0.0004 \\
(0.0001)^{* * *}\end{array}$ & $\begin{array}{c}0.0003 \\
(0.0002)\end{array}$ \\
\hline Year 2008 & $\begin{array}{l}0.0012 \\
(0.0001)^{* * *}\end{array}$ & $\begin{array}{l}0.0019 \\
(0.0005)^{* * *}\end{array}$ & $\begin{array}{l}0.0007 \\
(0.0002)^{* * *}\end{array}$ & $\begin{array}{l}0.0013 \\
(0.0003)^{* * * *}\end{array}$ \\
\hline Year 2009 & $\begin{array}{l}0.0013 \\
(0.0001)^{* * *}\end{array}$ & $\begin{array}{l}0.0017 \\
(0.0005)^{* * *}\end{array}$ & $\begin{array}{l}0.0009 \\
(0.0002)^{* * *}\end{array}$ & $\begin{array}{l}0.0016 \\
(0.0002)^{* * *}\end{array}$ \\
\hline Year 2010 & $\begin{array}{l}0.0013 \\
(0.0001)^{* * *}\end{array}$ & $\begin{array}{l}0.0026 \\
(0.0006)^{* * *}\end{array}$ & $\begin{array}{l}0.0007 \\
(0.0001)^{* * * *}\end{array}$ & $\begin{array}{l}0.0016 \\
(0.0002)^{* * *}\end{array}$ \\
\hline Year 2011 & $\begin{array}{l}0.0014 \\
(0.0001)^{* * *}\end{array}$ & $\begin{array}{l}0.0026 \\
(0.0005)^{* * *}\end{array}$ & $\begin{array}{l}0.0007 \\
(0.0001)^{* * * *}\end{array}$ & $\begin{array}{l}0.0019 \\
(0.0002)^{* * *}\end{array}$ \\
\hline Year 2012 & $\begin{array}{l}0.0021 \\
(0.0002) * * *\end{array}$ & $\begin{array}{l}0.0038 \\
(0.0006)^{* * *}\end{array}$ & $\begin{array}{l}0.0010 \\
(0.0002) * * *\end{array}$ & $\begin{array}{l}0.0027 \\
(0.0003)^{* * * *}\end{array}$ \\
\hline Year 2013 & $\begin{array}{l}0.0025 \\
(0.0002)^{* * *}\end{array}$ & $\begin{array}{l}0.0034 \\
(0.0006)^{* * *}\end{array}$ & $\begin{array}{l}0.0016 \\
(0.0002)^{* * *}\end{array}$ & $\begin{array}{l}0.0031 \\
(0.0003)^{* * *}\end{array}$ \\
\hline constant & $\begin{array}{l}-0.0004 \\
(0.0001)^{* * *}\end{array}$ & $\begin{array}{l}-0.0005 \\
(0.0002) * * *\end{array}$ & $\begin{array}{l}-0.0002 \\
(0.0001)^{* * *}\end{array}$ & $\begin{array}{l}-0.0006 \\
(0.0001)^{* * *}\end{array}$ \\
\hline $\begin{array}{c}\text { Fixed Effects (for pixels) } \\
\mathrm{N}\end{array}$ & $\begin{array}{c}\text { Yes } \\
744,632\end{array}$ & $\begin{array}{l}\text { Yes } \\
93,531\end{array}$ & $\begin{array}{c}\text { Yes } \\
352,607\end{array}$ & $\begin{array}{c}\text { Yes } \\
298,494\end{array}$ \\
\hline
\end{tabular}

Notes: $* p<0.1 ; * *<<0.05 ; * * * p<0.01$. Standard errors in parentheses. Standard errors clustered by pixel ID. This table summarizes the panel regressions for each of the five interventions. To save space, we omit year effects for PA regressions (all are similar to those above). 


\section{$\underline{5.3 \text { FSC-certified vs. Uncertified Concessions }}$}

TABLE 5

Concession Panel, All Annual Tree-Cover Losses Inside Logging Concessions During 2001-2013

\begin{tabular}{|c|c|c|c|c|}
\hline & $A l l$ & Madre de Dios & Loreto & Ucayali \\
\hline $\begin{array}{l}\text { Active FSC (any impact } \\
\text { additional to concession's) }\end{array}$ & $\begin{array}{c}0.0000 \\
(0.0006)\end{array}$ & $\begin{array}{l}-0.0007 \\
(0.0003)^{* *}\end{array}$ & $\begin{array}{c}0.0000 \\
(0.0003)\end{array}$ & $\begin{array}{c}0.0015 \\
(0.0027)\end{array}$ \\
\hline $\begin{array}{l}\text { Active Concession } \\
\text { (versus when inactive) }\end{array}$ & $\begin{array}{c}0.0001 \\
(0.0001)\end{array}$ & $\begin{array}{l}-0.0004 \\
(0.0005)\end{array}$ & $\begin{array}{c}0.0001 \\
(0.0001)\end{array}$ & $\begin{array}{l}0.0006 \\
(0.0002)^{* *}\end{array}$ \\
\hline Year $2002(1,0)$ & $\begin{array}{l}-0.0000 \\
(0.0000)\end{array}$ & $\begin{array}{c}0.0003 \\
(0.0003)\end{array}$ & $\begin{array}{l}-0.0000 \\
(0.0000)\end{array}$ & $\begin{array}{l}-0.0004 \\
(0.0001)^{* *}\end{array}$ \\
\hline Year $2003(1,0)$ & $\begin{array}{l}-0.0000 \\
(0.0001)\end{array}$ & $\begin{array}{c}0.0006 \\
(0.0005)\end{array}$ & $\begin{array}{l}-0.0001 \\
(0.0000)^{* *}\end{array}$ & $\begin{array}{l}-0.0006 \\
(0.0002)^{* * *}\end{array}$ \\
\hline Year $2004(1,0)$ & $\begin{array}{c}0.0001 \\
(0.0001)\end{array}$ & $\begin{array}{c}0.0007 \\
(0.0005)\end{array}$ & $\begin{array}{c}0.0000 \\
(0.0001)\end{array}$ & $\begin{array}{l}-0.0005 \\
(0.0002)^{* *}\end{array}$ \\
\hline Year $2005(1,0)$ & $\begin{array}{c}0.0001 \\
(0.0001)\end{array}$ & $\begin{array}{c}0.0005 \\
(0.0005)\end{array}$ & $\begin{array}{c}0.0000 \\
(0.0001)\end{array}$ & $\begin{array}{l}-0.0004 \\
(0.0002)^{*}\end{array}$ \\
\hline Year $2006(1,0)$ & $\begin{array}{c}0.0000 \\
(0.0001)\end{array}$ & $\begin{array}{c}0.0006 \\
(0.0005)\end{array}$ & $\begin{array}{l}-0.0001 \\
(0.0001)\end{array}$ & $\begin{array}{l}-0.0006 \\
(0.0002)^{* *}\end{array}$ \\
\hline Year $2007(1,0)$ & $\begin{array}{c}0.0001 \\
(0.0001)\end{array}$ & $\begin{array}{c}0.0008 \\
(0.0005)\end{array}$ & $\begin{array}{l}-0.0000 \\
(0.0001)\end{array}$ & $\begin{array}{l}-0.0005 \\
(0.0002)^{* *}\end{array}$ \\
\hline Year $2008(1,0)$ & $\begin{array}{l}0.0003 \\
(0.0001)^{* * *}\end{array}$ & $\begin{array}{c}0.0011 \\
(0.0006)^{*}\end{array}$ & $\begin{array}{c}0.0002 \\
(0.0001)\end{array}$ & $\begin{array}{l}-0.0001 \\
(0.0002)\end{array}$ \\
\hline Year $2009(1,0)$ & $\begin{array}{l}0.0006 \\
(0.0001)^{* * *}\end{array}$ & $\begin{array}{c}0.0008 \\
(0.0006)\end{array}$ & $\begin{array}{l}0.0004 \\
(0.0001)^{* * *}\end{array}$ & $\begin{array}{l}0.0007 \\
(0.0003)^{* * *}\end{array}$ \\
\hline Year $2010(1,0)$ & $\begin{array}{l}0.0005 \\
(0.0001)^{* * *}\end{array}$ & $\begin{array}{l}0.0014 \\
(0.0006)^{* *}\end{array}$ & $\begin{array}{l}0.0002 \\
(0.0001)^{* * * *}\end{array}$ & $\begin{array}{l}0.0004 \\
(0.0002)^{*}\end{array}$ \\
\hline Year $2011(1,0)$ & $\begin{array}{l}0.0006 \\
(0.0001)^{* * *}\end{array}$ & $\begin{array}{l}0.0014 \\
(0.0006)^{* *}\end{array}$ & $\begin{array}{l}0.0001 \\
(0.0000)^{* *}\end{array}$ & $\begin{array}{l}0.0007 \\
(0.0002)^{* * * *}\end{array}$ \\
\hline Year $2012(1,0)$ & $\begin{array}{l}0.0010 \\
(0.0002)^{* * *}\end{array}$ & $\begin{array}{l}0.0021 \\
(0.0008) * * *\end{array}$ & $\begin{array}{l}0.0005 \\
(0.0001)^{* * *}\end{array}$ & $\begin{array}{l}0.0011 \\
(0.0003)^{* * *}\end{array}$ \\
\hline Year $2013(1,0)$ & $\begin{array}{l}0.0013 \\
(0.0002)^{* * * *}\end{array}$ & $\begin{array}{l}0.0015 \\
(0.0006)^{* *}\end{array}$ & $\begin{array}{l}0.0005 \\
(0.0001)^{* * * *}\end{array}$ & $\begin{array}{l}0.0022 \\
(0.0005)^{* * * *}\end{array}$ \\
\hline constant & $\begin{array}{l}0.0002 \\
(0.0001)^{* *}\end{array}$ & $\begin{array}{c}0.0002 \\
(0.0002)\end{array}$ & $\begin{array}{l}0.0001 \\
(0.0001)^{*}\end{array}$ & $\begin{array}{c}0.0003 \\
(0.0002)\end{array}$ \\
\hline $\begin{array}{r}\text { Fixed Effects } \\
\text { (for concessions) }\end{array}$ & Yes & Yes & Yes & Yes \\
\hline $\mathrm{R}^{2}$ & 0.05 & 0.07 & 0.04 & 0.09 \\
\hline $\mathrm{N}$ & 6,825 & 1,183 & 3,315 & 2,327 \\
\hline
\end{tabular}

Notes: Standard errors in parentheses. $* \mathrm{p}<0.1 ; * * \mathrm{p}<0.05 ; * * * \mathrm{p}<0.01$. We used a panel of 525 concessions for the period 2001-2013. Therefore, we had a total of 6,825 observations. We clustered the standard errors by concession. 
Table 5's concession-unit panel shows no significant impact from certification, on average, relative to uncertified concessions in the whole study area, as well as in Loreto and Ucayali. Yet there is a significant effect of certification in Madre de Dios: a 0.07 percent fall in treecover loss, annually, implying a 1 percent reduction in tree-cover loss for 2000-2013.

Year effects are critical. Without them, certification is erroneously found to increase losses, given that later years have higher loss and certification began in 2006. These controls, then, avoid mistakenly assigning 'perverse' certification impact. We find an empirical suggestion that FSC certification is complementary to private governance in these logging concessions. In Madre de Dios, where concessions alone lower tree-cover loss, certification does too.

\section{Discussion}

To shed empirical light on development and conservation policies, and their combinations, we estimated the 2000-2013 forest impacts of several interventions in the Peruvian Amazon (specifically in the Madre de Dios, Loreto and Ucayali regions). We examined uncertified logging concessions, FSC certification of logging concessions, PAs for strict conservation, and four types of multiple-use PAs. For the entire study area, PAs lowered tree-cover loss, in contrast to the lack of average impacts for uncertified logging concessions and for FSC.

We also got interesting insights from variations in policy impacts. Uncertified concessions lowered tree-cover loss in Madre de Dios, i.e., firms sometimes successfully defend forest given extraction rights by excluding others. In contrast, uncertified concessions alone led to increased loss of tree-cover in Ucayali, where firms either failed to exclude other actors who log or deforest - or logged more than was permitted based on their own motivations. 
This striking variation in concessions' impacts may be due to differences in access to Lima, lower timber production costs in Ucayali, or different markets as the concessions in Madre de Dios export valuable species, while Ucayali sells less valuable timber into local markets (interviewee 12, personal communication, February, 2016). Therefore, these concessions results suggest roles in forest conservation of both forest governance and private drivers.

Variation in uncertified concessions' willingness and capacity to lower loss might explain why FSC had impacts only in Madre de Dios (reducing 2000-2013 forest loss $\sim 1$ percent). The result is also consistent with claims of greater effort in FSC implementation, including by international actors motivated by species of interest or perceptions of strong governance and private capacity. Either way, FSC impacts may reflect variation in governance inputs.

Even though all types of PAs reduced tree-cover loss in the entire study area, on average, forest impacts from conservation policies also included loss, as strict PAs in Madre de Dios slightly raised rates of tree-cover loss. That highlights potentially limited public monitoring and enforcement, raising questions about private actors' possible roles in local governance, e.g., in multiple-use PAs. For the entire study area and each region, we found multiple-use PAs had greater forest gains (more reduction in tree-cover loss rates), relative to strict PAs.

In sum, our results highlight the importance of forest governance and suggest the feasibility of forest-conservation benefits from policies that facilitate selective development needs. Of course, in comparing interventions we also would like to consider costs, and thus net gains, across policy options. Unfortunately, costs for these policies are not available at this time.

Turning to methods and data, given spatially precise yet broad forest coverage over time we 
believe our impact estimates help advance impact evaluation of forest policies by applying panel approaches for removing the influences of fixed differences over space and time when most past forest policy evaluations have relied on cross-sectional methods. We stress that this method cannot address unmeasured differences between units that vary over time. However, given numerous sets of influences on forests that vary across either space or time - including many for which reliable metrics are not available - there is great value in panel analysis with both unit and year effects. Without such effects, estimates can change sign.

Moving forward, we believe it is critical to improve the data. One useful addition would be information about the settings for FSC certification - including characteristics of the firms, given that it is quite possible that different types of companies employ FSC differently. For example, multinational corporations constrained by trade rules and aware that monitoring is imperfect could employ the FSC label from one concession to 'green wash' the exports from other land not managed to FSC standards, while domestic small firms do not get such gains generally. Thus, firm size could affect use of and impacts of FSC certification, since firms' motivations and constraints differ. To better understand such differences, FSC could collect firm characteristics - plus all the information ideally contained in forest management plans (e.g., techniques, volumes, and species). Data on costs of FSC also would aid in evaluating the net benefits or costs of certification. Unfortunately, these data are currently incomplete.

Turning to our control group, geospatial data on institutions that influence forests outside of PAs and concessions also are incomplete. We followed the literature in using as controls all forest outside policies of interest. While formal and informal institutions exist in our study area, as they do globally, useful spatial data were not available at the time of this analysis. 
Another refinement of interventions data concerns when interventions effectively end - if that differs from when they officially end. If a concession or a PA has become inactive but officially has not been terminated, then treating an area as active biases impact evaluations.

In terms of outcomes metrics, the data we used on tree-cover loss has some limits including interpretations of some plantations as forest (Tropek et al., 2014). Improved forest data also may help identify more subtle differences between treatment and control forests, as well as help us to focus spatially, e.g., upon selective logging areas inside concessions. The latter is important because forest impacts of improved management might be near logging roads. However, more precise data, with higher definition, are only available for smaller areas. Investments in data ideally will improve all future analyses - yet consistent mapping and monitoring of very detailed forest-cover changes for large regions will remain a challenge.

To build upon our assessments, future studies could use other indicators of forest impacts. Certainly, there are measures of forest fires that could indicate impacts of management. Selective logging's and, thus, certification's impacts may be changes in forest degradation, i.e., subtler changes in forest quality that yet are critical for providing ecosystem services. Degradation may be detected using remote-sensing data techniques with field investigations (though, like deforestation, its definition can vary). Yet high-resolution and well tested data were not available for this study and processing such data is outside the scope of this study. Still, we strongly expect a trend of improvement in evaluations as data improve many ways. 


\section{References}

Agrawal, A., Chhatre, A. \& Hardin, R. (2008). Changing governance of the world's forests. Science 320: 1460-1462.

Albers, H.J. (2010). Spatial modeling of extraction and enforcement in developing country protected areas. Resource and Energy Economics 32, 165-179.

Andam, K. S., Ferraro, P. J., Pfaff, A., Sanchez-Azofeifa, G. A., \& Robalino, J. A. (2008). Measuring the effectiveness of protected area networks in reducing deforestation. Proceedings of the National Academy of Sciences, 105(42), 1608916094.

Arent, D.J., R.S.J. Tol, E. Faust, J.P. Hella, S. Kumar, K.M. Strzepek, F.L. Tóth, and D. Yan (2014). Key economic sectors and services. In: Climate Change 2014: Impacts, Adaptation, and Vulnerability. Part A: Global and Sectoral Aspects. Contribution of Working Group II to the Fifth Assessment Report of the Intergovernmental Panel on Climate Change [Field, C.B., V.R. Barros, D.J. Dokken, K.J. Mach, M.D. Mastrandrea, T.E. Bilir, M. Chatterjee, K.L. Ebi, Y.O. Estrada, R.C. Genova, B. Girma, E.S. Kissel, A.N. Levy, S. MacCracken, P.R. Mastrandrea, \& L.L. White (eds.)]. Cambridge University Press, Cambridge, United Kingdom and New York, NY, USA, pp. 659-708.

Auld, G., Gulbrandsen, L.H. \& McDermott, C.L. (2008). Certification schemes and the impacts on forests and forestry. Annual Rev. of Envir. and Resources 33, 187-211

Blackman, A., Goff, L. T., \& Rivera Planter, M. (2018). Does Eco-certification Stem Tropical Deforestation? Forest Stewardship Council Certification in Mexico. Journal of Environmental Economics and Management, Volume 89, pp. 306-333, https://doi.org/10.1016/j.jeem.2018.04.005.

Blackman, A., Raimondi, A., \& Cubbage, F. (2014). Does Forest Certification in Developing Countries Have Environmental Benefits? Insights from Mexican Corrective Action Requests, Resources for the Future Discussion Paper No. 14-06.

Breukink, G., Levin, J., \& Mo, K. (2015). Profitability and Sustainability in Responsible Forestry. Economic impacts of FSC certification on forest operators. Retrieved from http://d2ouvy59p0dg6k.cloudfront.net/downloads/profitability_and_sustainability_i n_responsible_forestry_main_report_final.pdf

Burivalova, Z., Hua, F., Koh, L. P., Garcia, C., \& Putz, F. (2017). A critical comparison of conventional, certified, and community management of tropical forests for timber in terms of environmental, economic, and social variables. Conservation Letters, 10(1), 4-14.

Counsell, S., \& Loraas, K. T. (2002). Trading in credibility: the myth and reality of the Forest Stewardship Council. (Retrieved from http://globalforestcoalition.org/wpcontent/uploads/2010/12/Trading-in-Credibility1.pdf) 
DeFries, R.S., Rudel, T., Uriarte, M., \& Hansen, M. (2010). Deforestation driven by urban population growth and agricultural trade in the twenty-first century. Nature Geoscience 3: 178-181.

European Forest Institute (2014). What is the EU FLEGT Action Plan? EU FLEGT Facility. Retrieved from http://www.euflegt.efi.int/43

ESRI. (2014). ArcGIS 10.2.2 for Desktop. Redlands, CA: Envir. Systems Research Institute.

Food and Agriculture Organization of the United Nations (FAO). (2015a). Global Forests Resources Assessment 2015. Rome (http://www.fao.org/3/a-i4793e.pdf ).

Food and Agriculture Organization of the United Nations (FAO). (2015b). Making forest concessions work to sustain forests, economies and livelihoods in tropical timber producing countries. Retrieved from http://www.fao.org/forestry/4407508960f20f3f0a4e82224fa19b65812a22.pdf

Finer, M., Jenkins, C. N., Sky, M. A. B., \& Pine, J. (2014). Logging Concessions Enable Illegal Logging Crisis in the Peruvian Amazon. Scientific Reports, 4719(4), 1-6.

Forest Stewardship Council (FSC). (2018). Facts \& Figures February 2018. Retrieved from https://ic.fsc.org/en/facts-and-figures

Forest Stewardship Council (FSC). (2015a). Our vision and mission. Retrieved from https://ic.fsc.org/vision-mission.12.htm.

Forest Stewardship Council (FSC). (2015b). Internally generated data. Retrieved from https://ic.fsc.org/internally-generated-data.183.htm.

Forest Stewardship Council (FSC) Peru. (2017). Iniciativas Certificadas en el Perú Retrieved from https://pe.fsc.org/es-pe/nuestro-impacto/datos-y-cifras

Hale, T. \& Held, D. (2011) Handbook of Transnational Governance. Cambridge: Polity Press

Hansen, M. C., Potapov, P. V., Moore, R., Hancher, R., Turubanova, S. A., Tyukavina, A., Thau, D., Stehman, S.V., Goetz, S.J., Loveland, T.R., Kommareddy, A., Egorov, A., Chini, L., Justice, C.O., \& Townshend, J.R.G. (2013). High-Resolution Global Maps of 21st-Century Forest Cover Change. Science, 342 (6160): 850-53. Data at: http://earthenginepartners.appspot.com/science-2013-global-forest.

Hijmans, R. J., Cameron, S. E., Parra, J. L., Jones, P. G., \& Jarvis, A. (2005). Very high resolution interpolated climate surfaces for global land areas. International journal of climatology, 25(15), 1965-1978.

Jarvis, A., Reuter, H. I., Nelson, A., \& Guevara, E. (2008). Hole-filled SRTM for the globe Version 4. available from the CGIAR-CSI SRTM 90m Database (http://srtm. csi. cgiar. org). 
Joppa, L. N., \& Pfaff, A. (2011). Global protected area impacts. Proceedings. Biological Sciences / The Royal Society, 278(1712), 1633-8.

Joppa, L. \& Pfaff, A. (2010). Reassessing the forest impacts of protection: the challenge of nonrandom location and a corrective method. Annals of the New York Academy of Sciences, 1185, 135-149.

Joppa, L. N., \& Pfaff, A. (2009). High and far: biases in the location of protected areas. PloS one, 4(12), e8273.

Laurance, W. F. (1999). Reflections on the tropical deforestation crisis. Biological Conservation, 91(2), 109-117.

Laurance, W. F., Cochrane, M. A., Bergen, S., Fearnside, P. M., Delamônica, P., Barber, C., ... \& Fernandes, T. (2001). The future of the Brazilian Amazon. Science, 291(5503), 438-439.

Laurance, W. F., Ferreira, L. V., Rankin-de Merona, J. M., \& Laurance, S. G. (1998). Rain forest fragmentation and the dynamics of Amazonian tree communities. Ecology, 79(6), 2032-2040.

Ministerio del Ambiente. (2015). Los Bosques en cifras. Retrieved August 13, 2015, from http://www.minam.gob.pe/bosques/los-bosques-en-cifras/

Ministerio del Ambiente, \& Ministerio de Agricultura. (2011). El Perú de los Bosques. Lima, Perú.

Miranda, J. J., Corral, L., Blackman, A., Asner, G., \& Lima, E. (2016). Effects of Protected Areas on Forest Cover Change and Local Communities: Evidence from the Peruvian Amazon. World Development, 78, 288-307. doi:10.1016/j.worlddev.2015.10.026

Miteva, D. A., Loucks, C. J., \& Pattanayak, S. K. (2015). Social and environmental impacts of forest management certification in Indonesia. PloS one, 10(7), e0129675.

Nebel, G., Quevedo, L., Jacobsen, J.B., \& Helles, F. (2005). Development and economic significance of forest certification: the case of FSC in Bolivia. Forest Policy and Economics, 7(2), 175-186.

Nelson, A., \& Chomitz, K. M. (2011). Effectiveness of strict vs. multiple use protected areas in reducing tropical forest fires: a global analysis using matching methods. PLoS One, 6(8), e22722.

Oliveira, P. J. C., Asner, G. P., Knapp, D. E., Almeyda, A., Galván-Gildemeister, R., Keene, S., ...Smith, R. C. (2007). Land-use allocation protects the Peruvian Amazon. Science (New York, N.Y.), 317(5842), 1233-6. doi: $10.1126 /$ science. 1146324 
Pfaff, A., Robalino, J. \& Herrera, D. (2018). Decentralization given environmentdevelopment tradeoffs: Federal versus state conservation and impacts on Amazon deforestation. Mimeo, Duke University

Pfaff, A., F. Santiago-Avila and L. Joppa (2017). Evolving Protected-Area Impacts in Mexico: political shifts as suggested by impact evaluations. Forests 8(17) doi:10.3390/f8010017.

Pfaff, A., Robalino, J., Herrera, D., \& Sandoval, C. (2015a). Protected Areas' Impacts on Brazilian Amazon Deforestation: Examining Conservation - Development Interactions to Inform Planning. PLOS ONE, 1-17. http://doi.org/10.1371/journal.pone.0129460

Pfaff, A., Robalino, J., Sandoval, C., \& Herrera, D. (2015b). Protected Area Types, Strategies, and Impacts in Brazil's Amazon: public protected area strategies do not yield a consistent ranking of PA types by impact. Phil. Trans. R. Soc. B, 370(1681), 20140273.

Pfaff, A., Amacher, G. S., \& Sills, E. O. (2013). Realistic REDD : Improving the Forest Impacts of Domestic Policies in Different Settings. Review of Environmental Economics and Policy, 7(1), 114-135. http://doi.org/10.1093/reep/res023

Rainforest Alliance. (2014). Community Forestry in Peru. Retrieved May 28, 2014, from http://www.rainforest-alliance.org/work/community-forestry/regions/peru

Rana, P. \& Sills, E.O. (2018). Does Certification Change the Trajectory of Tree Cover in Working Forests in the Tropics? An Application of the Synthetic Control Method of Impact Evaluation. Forests 9(98) doi:10.3390/f9030098

Raschio, G., Contreras, C., \& Schlesinguer, (2014). Análisis de agentes y causas de la deforestación y degradación forestal para la región de Madre de Dios, Perú. Report to World Wildlife Fund/Peru. April 2014.

República del Perú. Ley de Áreas Naturales Protegidas (Ley No. 26834) (1997).

República del Perú. Ley Forestal y Fauna Silvestre (Ley No. 27308) (2000).

República del Perú. Resolución Presidencial N.006-2013-OSINFOR (2013a).

República del Perú. Resolución Presidencial N.007-2013-OSINFOR (2013b).

Sears, R. R., \& Pinedo-Vasquez, M. (2011). Forest Policy Reform and the Organization of Logging in Peruvian Amazonia. Development and Change, 42(2), 609-631.

Solano, P. (2010). Legal Framework for Protected Areas: Peru. Gland, Switzerland. IUC

StataCorp. (2013). Stata: Release 13. Statistical Software. Retrieved from http://www.stata.com/manuals13/te.pdf 
Swenson, JJ., Carter, C.E., Domec, J.C., \& Delgado, C.I. (2011). Gold Mining in the Peruvian Amazon: Global Prices, Deforestation, and Mercury Imports. PloSONE. doi:10.1371/journal.pone.0018875

Thünen, J. V. (1826). Der isolierte Staat. Beziehung auf Landwirtschaft und Nationalökonomie.

Tropek, R., Sedláček, O., Beck, J., Keil, P., Musilová, Z., Šímová, I., \& Storch, D. (2014). Comment on "High-resolution global maps of 21st-century forest cover change". Science 344(6187) 6187: 981.

Urrunaga, J.M., Johnson, A., Orbegozo, I.D., \& Mulligan, F. (2012). The Laundering Machine: How Fraud and Corruption in Peru's Concession System are Destroying the Future of its Forests. Washington, DC: Environmental Investigation Agency Retrieved from http://eia-global.org/news-media/the-laundering-machine

Van der Werf, G. R., Morton, D. C., DeFries, R. S., Olivier, J. G., Kasibhatla, P. S., Jackson, R. B., Collatz, G.J. \& Randerson, J. T. (2009). CO2 emissions from forest loss. Nature geoscience, 2(11), 737-738.von Thunen, Johann H. (1826). "Der isolierte Staat in Beziehung der Landwirtschaft und Nationalo"konomie" (1996, Transl.). In von Thünen's The Isolated State, ed. Peter Hall. Oxford, UK: Pergamon Press.

Villalobos, L., Coria, J., \& Nordén, A. (2018). Has Forest Certification Reduced Forest Degradation in Sweden?. Land Economics, 94(2), 220-238.

Wright, S.J. \& Muller-Landau, H.C. (2006). The Future of Tropical Forest Species. Biotropica 38(3): 287-301.

World Wildlife Fund. (2015). GFTN-Peru. Retrieved from http://gftn.panda.org/gftn_worldwide/latin_america/peru/ 


\section{FIGURE 1}

\section{Loreto Region in Peru}

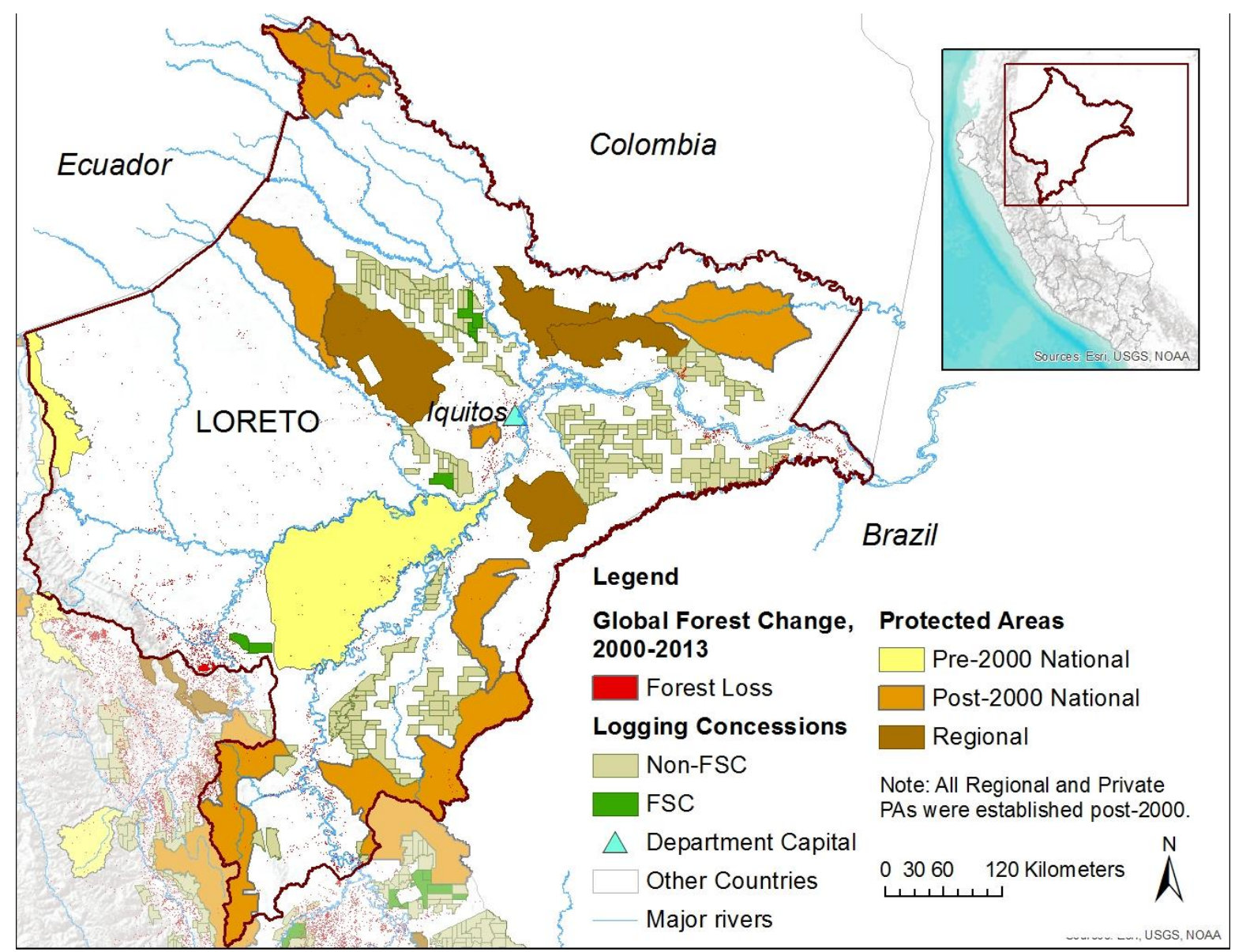

Sources: Global Forest Change, MINAM, MINAG, SERNANP, Esri, HERE, De Lorme, TomTom, Intermap, increment P Corp., GEBCO, USGS, FAO, NPS, NRCAN, GeoBase, IGN, Kadaster NL, Ordance Survey, Esri Japan, METI, Esri China (Hong Kong), swisstopo, MapmyIndia, OpenStreetMap contributors, and the GIS User Community 


\section{FIGURE 2}

\section{Peru's Ucayali and Madre de Dios Regions}

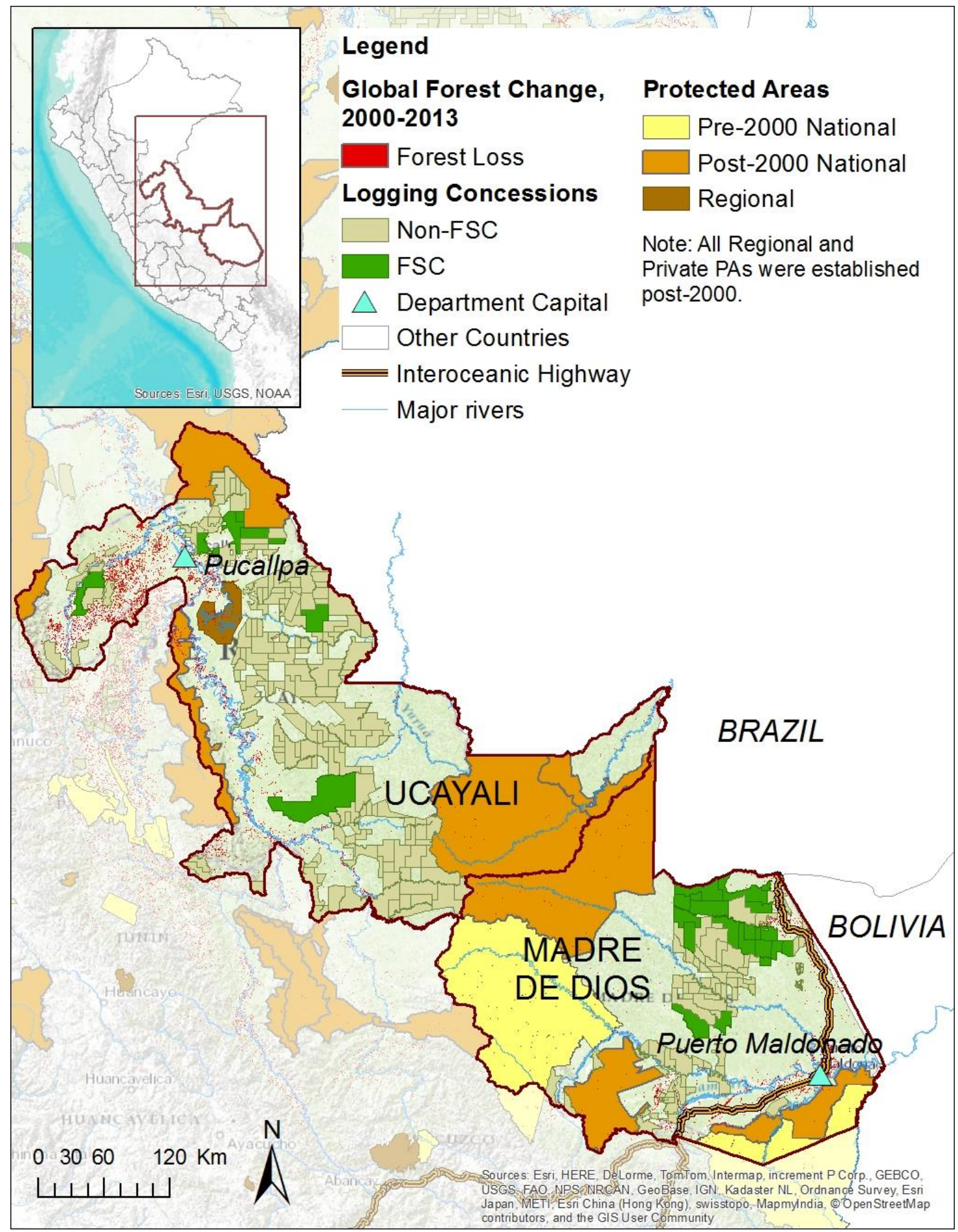

Sources: Global Forest Change, MINAM, MINAG, SERNANP, Esri, HERE, De Lorme, TomTom, Intermap, increment P Corp., GEBCO, USGS, FAO, NPS, NRCAN, GeoBase, IGN, Kadaster NL, Ordance Survey, Esri Japan, METI, Esri China (Hong Kong), swisstopo, MapmyIndia, OpenStreetMap contributors, and the GIS User Community. 
Appendix 1. Protected Areas (our impacts are estimated for the seventeen post-2000 PAs)

\begin{tabular}{|c|c|c|c|}
\hline Protected Area & Type & Year & Affected In Our Area \\
\hline Pacaya Samiria & National, Direct Use & 1972 & Loreto \\
\hline del Manu & National, Indirect Use & 1973 & Madre de Dios \\
\hline Bahuaja Sonene & National, Indirect Use & 1996 & Madre de Dios \\
\hline Santiago Comaina & National, Reserved Zone & 1999 & Loreto \\
\hline Tambopata & National, Direct Use & 2000 & Madre de Dios \\
\hline El Sira & National, Direct Use & 2001 & Ucayali \\
\hline Cordillera Azul & National, Indirect Use & 2001 & Loreto \& Ucayali \\
\hline Amarakaeri & National, Direct Use & 2002 & Madre de Dios \\
\hline Purus & National, Direct Use & 2004 & Ucayali \& Madre de Dios \\
\hline Alto Purus & National, Indirect Use & 2004 & Ucayali \& Madre de Dios \\
\hline Allpahuayo Mishana & National, Direct Use & 2004 & Loreto \\
\hline Sierra del Divisor & National, Reserved Zone & 2006 & Loreto \& Ucayali \\
\hline Matsés & National, Direct Use & 2009 & Loreto \\
\hline Comunal Tamshiyacu Tahuayo & Regional & 2009 & Loreto \\
\hline Pucacuro & National, Direct Use & 2010 & Loreto \\
\hline Imiria & Regional & 2010 & Ucayali \\
\hline Ampiyacu Apayacu & Regional & 2010 & Loreto \\
\hline Yaguas & National, Reserved Zone & 2011 & Loreto \\
\hline Alto Nanay- Pintuyacu Chambira & Regional & 2011 & Loreto \\
\hline Güeppi-Sekime & National, Indirect Use & 2012 & Loreto \\
\hline Huimeki & National, Direct Use & 2012 & Loreto \\
\hline Airo Pai & National, Direct Use & 2012 & Loreto \\
\hline
\end{tabular}

Note: We have excluded from our analyses a Regional PA that was created in 2015 , i.e., after the end of our study period. Source: SERNANP

Appendix 2. Fixed Covariates (for matching, noting panel analyses add fixed \& year effects)

\begin{tabular}{|l|l|l|}
\hline Type & Variable & Justification \\
\hline Market access & Distance to roads $(\mathrm{km})$ & $\begin{array}{l}\text { Forests closer to roads are more accessible and, thus, face more } \\
\text { of many pressures that generate forest loss. }\end{array}$ \\
\cline { 2 - 3 } & Distance to major cities $(\mathrm{km})$ & The forests closer to markets also face more pressures. \\
\cline { 2 - 3 } Biophysical & Distance to rivers $(\mathrm{km})$ & $\begin{array}{l}\text { In Ucayali and Loreto, logs are transported via rivers: closer to } \\
\text { rivers has a higher probability of forest loss. }\end{array}$ \\
\hline & $\begin{array}{l}\text { Elevation }(\mathrm{m}) \\
\text { Slope }(\text { degrees }) \\
\text { Precipitation }(\mathrm{mm})\end{array}$ & $\begin{array}{l}\text { All of these biophysical characteristics of a location can } \\
\text { significantly affect what grows and costs of production, and } \\
\text { thus agricultural profit and pressures for forest loss. However, } \\
\text { they do not vary a great deal across our area. }\end{array}$ \\
\hline
\end{tabular}

Sources: Authors' elaboration with information from Andam et al. (2008) 


\section{Appendix 3. Covariate Balances Resulting from Different Approaches to Pixel Matching}

\begin{tabular}{|c|c|c|c|c|c|}
\hline $\begin{array}{l}\text { UNCERTIFIED } \\
\text { CONCESSIONS }\end{array}$ & Treated & $\begin{array}{c}\text { All } \\
\text { Controls } \\
\text { (no match) }\end{array}$ & $\begin{array}{c}\text { Matched } \\
\text { Controls } \\
\text { (PSM, without } \\
\text { replacement) } \\
\end{array}$ & $\begin{array}{c}\text { Matched } \\
\text { Controls } \\
\text { (PSM, with } \\
\text { replacement) } \\
\end{array}$ & $\begin{array}{c}\text { Matched } \\
\text { (Covariate, } \\
\text { replacement \& } \\
\text { by region) } \\
\end{array}$ \\
\hline Distance to Capital & 170.52 & $191.60 * * *$ & $172.75 * * *$ & $171.52 *$ & 169.93 \\
\hline Distance to River & 22.06 & $18.63 * * *$ & $21.41 * * *$ & $21.39 * * *$ & $21.89 *$ \\
\hline Distance to Road & 55.69 & $47.49 * * *$ & $58.46 * * *$ & $57.81 * * *$ & $55.26^{*}$ \\
\hline Loreto & 0.44 & $0.75 * * *$ & 0.43 & 0.40 & 0.44 \\
\hline Ucayali & 0.43 & $0.15^{* * *}$ & $0.41 * * *$ & $0.41 * * *$ & 0.43 \\
\hline mean bias & & 41.3 & 3.9 & 3.3 & 0.7 \\
\hline \multicolumn{6}{|l|}{ INDIRECT USE } \\
\hline Distance to Capital & 273.97 & $191.60 * * *$ & $248.74 * * *$ & $241.62 * * *$ & $255.45 * * *$ \\
\hline Distance to River & 18.98 & $18.63 * * *$ & $14.76 * * *$ & $13.95 * * *$ & $17.17 * * *$ \\
\hline Distance to Road & 97.23 & $47.49 * * *$ & $109.49 * * *$ & $84.47 * * *$ & $93.65 * * *$ \\
\hline Loreto & 0.26 & $0.75 * * *$ & $0.23 * * *$ & $0.34 * * *$ & 0.26 \\
\hline Ucayali & 0.38 & $0.15 * * *$ & $0.48 * * *$ & 0.38 & 0.38 \\
\hline mean bias & & 78.6 & 23.9 & 24.9 & 10.0 \\
\hline \multicolumn{6}{|l|}{ DIRECT USE } \\
\hline Distance to Capital & 243.60 & $191.60 * * *$ & $240.11 * * *$ & $240.09 * * *$ & 242.39 \\
\hline Distance to River & 24.78 & $18.63 * * *$ & $26.38 * * *$ & $26.27 * * *$ & $24.45^{* *}$ \\
\hline Distance to Road & 40.50 & $47.49 * * *$ & $39.79 * *$ & $39.64 * *$ & $39.76 * *$ \\
\hline Loreto & 0.65 & $0.75 * * *$ & 0.65 & 0.65 & 0.65 \\
\hline Ucayali & 0.18 & $0.15 * * *$ & $0.19 *$ & $0.19 * *$ & 0.18 \\
\hline mean bias & & 29.9 & 4.0 & 3.9 & 1.4 \\
\hline \multicolumn{6}{|l|}{ RESERVED } \\
\hline Distance to Capital & 183.63 & $191.60 * * *$ & $186.35 * * *$ & $186.38 * * *$ & 183.03 \\
\hline Distance to River & 23.30 & $18.63 * * *$ & $24.01 * * *$ & $24.20 * * *$ & 23.02 \\
\hline Distance to Road & 90.74 & $47.49 * * *$ & $91.68 * *$ & $91.56^{*}$ & $89.18 * * *$ \\
\hline Ucayali & 0.22 & $0.15^{* * *}$ & $0.19 * * *$ & $0.19 * * *$ & 0.22 \\
\hline mean bias & & 41.1 & 4.0 & 4.2 & 1.5 \\
\hline \multicolumn{6}{|l|}{ REGIONAL } \\
\hline Distance to Capital & 129.58 & $191.60 * * *$ & $121.38 * * *$ & $122.10 * * *$ & 129.31 \\
\hline Distance to River & 36.05 & $18.63 * * *$ & $34.15 * * *$ & $33.47 * * *$ & $35.49 * *$ \\
\hline Distance to Road & 67.01 & $47.49 * * *$ & $64.42 * * *$ & $65.14 * * *$ & $66.24 * *$ \\
\hline Loreto & 0.94 & $0.75^{* * *}$ & 0.94 & 0.94 & 0.94 \\
\hline mean bias & & 77.3 & 8.0 & 8.1 & 1.8 \\
\hline
\end{tabular}

